\title{
COMMENTARY
}

\section{Acute respiratory distress syndrome during neutropenia recovery}

\author{
Élie Azoulay* and Michael Darmon \\ See related research by Rhee et al., http://ccforum.com/content/13/6/R173
}

\begin{abstract}
Acute respiratory failure is a life-threatening complication in cancer patients. During neutropenia, patients are at high risk for bacterial pneumonia or invasive fungal infections, when neutropenia is prolonged. A high proportion of patients in whom neutropenia had been complicated by pneumonia will present with substantial respiratory deterioration during neutropenia recovery. Patients with fungal pneumonia and those receiving granulocyte colony-stimulating factor to shorten neutropenia duration may be at higher risk for this acute lung injury/acute respiratory distress syndrome during neutropenia recovery. Routine screening of patient's risk factors is crucial since first symptoms of acute respiratory distress syndrome may occur before biological leukocyte recovery.
\end{abstract}

Cancer chemotherapy is administered every day to numerous cancer patients, with neutropenia mostly a normally expected event [1,2]. During neutropenia, bacterial sepsis remains a major threat [3]. Potential sources of infection include primarily the lungs, the digestive tract, and the bloodstream [4,5]. Some of the patients with prolonged neutropenia are more likely to present with nonbacterial infections, namely acute leukemia patients and stem cell/bone marrow transplant recipients [6]. Although neutrophils are believed to have a pivotal role in the pathophysiology of acute lung injury (ALI) and acute respiratory distress syndrome (ARDS), early evidence emerged that neutropenic patients were not spared from ALI and ARDS [7]. Several hypotheses have been raised, including alveolar macrophage or monocyte deactivation [8] in relation to malignancy, cancer chemotherapy or sepsis.

*Correspondence: elie.azoulay@sls.aphp.fr

AP-HP, Hôpital Saint-Louis, Medical ICU, University Paris-7 Paris-Diderot, UFR de Médecine, 1 avenue Claude Vellefaux, 75010 Paris, France
Neutropenia recovery occurs silently in the vast majority of patients. Deterioration of the respiratory status, however, has been reported during resolution of leukopenia $[9,10]$ - that is, 2 to 3 days before and after the neutrophil count reaches $500 / \mathrm{mm}^{3}$ or the leukocyte count reaches $1,000 / \mathrm{mm}^{3}$ [11]. An aggravating role of granulocyte colony-stimulating factor (G-CSF) has been suggested in both clinical and experimental findings $[12,13]$. Patients at risk for ALI/ARDS during neutropenia recovery are those with pulmonary infiltrates during neutropenia $[10,12,13]$. Other risk factors that have been suggested include delayed or prolonged neutropenia [10] and invasive pulmonary aspergillosis [14].

In the previous issue of Critical Care, Rhee and coworkers assessed the risk factors for ARDS in 71 critically ill patients with hematologic malignancies and long-lasting neutropenia [1]. All of the patients received G-CSF. About one-half of the patients developed ARDS during neutropenia recovery. The authors identified that patients presenting pneumonia during neutropenia were at higher risk of ARDS during neutropenia recovery.

The present study provides additional evidence that neutropenic patients presenting clinically or microbiologically documented pneumonia should be monitored carefully at the time of neutropenia recovery. The study also raises the issue of G-CSF-related pulmonary toxicity in this context [15]. There are, however, three potential sources of bias in the study that should be highlighted.

First, one-half of the patients had an acute leukemia, all of them receiving G-CSF. Although the safety of G-CSF in patients with acute leukemia has been well established in numerous clinical trials, its potential advantages remain inconclusive since there is no evidence of a reduction in the overall frequency of infectious complications or the duration of hospitalization, nor any benefit in terms of disease-free survival or overall survival [16]. The benefit-risk ratio of G-CSF in these patients should therefore be carefully addressed in each individual case.

Second, the neutropenia duration was rather long in the present study (22.5 days), which is in agreement with the fact that $90 \%$ of the patients received chemotherapy 
for acute leukemia. Prolonged neutropenia has been identified as a risk factor for respiratory deterioration during neutropenia recovery [10]. This also indicates that the $50 \%$ incidence and the severity of respiratory deterioration during neutropenia recovery reported in Rhee and colleagues' study may not be generalizable to all patients with hematological malignancies such as diffuse B-cell lymphoma or myeloma, and even less to patients with solid tumors.

Third, the mortality rate reported in the study is in the higher ranges of recently published data $[17,18]$. This is probably further proof that patients reported in the paper by Rhee and coworkers are among the sickest critically ill leukemic patients. Along this line, the absence of documented invasive aspergillosis in the study is a surprising finding.

Although no sound causal relationship can be established from these data between neutropenia recovery and ARDS, we would like to emphasize the five convincing arguments supporting the reality of ARDS during neutropenia that the authors developed in their discussion section. First, a high proportion of patients in whom neutropenia had been complicated by pneumonia will present with substantial respiratory deterioration during neutropenia recovery. Also, the incidence of ALI/ ARDS in neutropenic patients with pneumonia is far higher during than before or after neutropenia recovery. Third, several groups from different parts of the world have described this clinical entity. Further, the experimental models of ALI/ARDS in neutropenic rats have been able to reproduce this condition with reasonable pathophysiology hypotheses. Finally, this ARDS situation is clinically plausible in these frail lung's patients with established predisposition to infections [19], cancer chemotherapy and G-CSF-induced pulmonary toxicity, and sometimes to pulmonary infiltration by the malignancy.

In the future, early recognition of those patients likely to present ALI/ARDS in this specific clinical setting is a worthwhile endeavor. The relevance of routine screening for each individual patient's risk factors is made crucial by the fact that the first symptoms of ARDS may occur before biological leukocyte recovery, and by the need to weight the benefit-risk ratio of G-CSF administration in every patient with clinically or microbiologically pneumonia complicating neutropenia.

\section{Abbreviations}

$\mathrm{ALI}=$ acute lung injury; $\mathrm{ARDS}=$ acute respiratory distress syndrome; G-CSF = granulocyte colony-stimulating factor.

\section{Acknowledgement}

The present work was supported by a grant from the Assistance-Publique Hôpitaux de Paris (AOM 04139).

\section{Competing interests}

The authors declare that they have received grants from Pfizer and Gilead but not in relation to this publication.
Published: 10 February 2010

\section{References}

1. Rhee CK, Kang JY, Kim YH, Kim JW, Yoon HK, Kim SC, Kwon SS, Kim YK, Kim KH, Moon HS, Park SH, Kim HJ, Lee S, Song JS: Risk factors for acute respiratory distress syndrome during neutropenia recovery in patients with hematologic malignancies. Crit Care 2009, 13:R173.

2. Coleman MP, Quaresma M, Berrino F, Lutz JM, De Angelis R, Capocaccia R, Baili P, Rachet B, Gatta G, Hakulinen T, Micheli A, Sant M, Weir HK, Elwood JM, Tsukuma H, Koifman S, E Silva GA, Francisci S, Santaquilani M, Verdecchia A, Storm HH, Young JL; CONCORD Working Group: Cancer survival in five continents: a worldwide population-based study (CONCORD). Lancet Oncol 2008, 9:730-756.

3. Bodey GP: Infection in cancer patients. A continuing association. Am J Med 1986, 81:11-26.

4. Cartoni C, Dragoni F, Micozzi A, Pescarmona E, Mecarocci S, Chirletti P, Petti MC, Meloni G, Mandelli F: Neutropenic enterocolitis in patients with acute leukemia: prognostic significance of bowel wall thickening detected by ultrasonography. J Clin Oncol 2001, 19:756-761.

5. Puig N, De La Rubia J, Jarque I, Salavert M, Moscardó F, Sanz J, Lorenzo I, Montesinos P, Martín G, Martínez J, Sanz G, Blanes M, Sanz M: Characteristics of and risk factors for pneumonia in patients with hematological malignancies developing fever after autologous blood stem cell transplantation. Leuk Lymphoma 2007, 48:2367-2374.

6. Darmon M, Azoulay E, Alberti C, Fieux F, Moreau D, Gall JR, Schlemmer B: Impact of neutropenia duration on short-term mortality in neutropenic critically ill cancer patients. Intensive Care Med 2002, 28:1775-1780.

7. Ognibene FP, Martin SE, Parker MM, Schlesinger T, Roach P, Burch C, Shelhamer JH, Parrillo JE: Adult respiratory distress syndrome in patients with severe neutropenia. N Engl J Med 1986, 315:547-551.

8. Mokart D, Kipnis E, Guerre-Berthelot P, Vey N, Capo C, Sannini A, Brun JP, Blache JL, Mege JL, Blaise D, Guery BP: Monocyte deactivation in neutropenic acute respiratory distress syndrome patients treated with granulocyte colony-stimulating factor. Crit Care 2008, 12:R17.

9. Rinaldo JE, Borovetz $\mathrm{H}$ : Deterioration of oxygenation and abnormal lung microvascular permeability during resolution of leukopenia in patients with diffuse lung injury. Am Rev Respir Dis 1985, 131:579-583.

10. Azoulay E, Darmon M, Delclaux C, Fieux F, Bornstain C, Moreau D, Attalah H, Le Gall JR, Schlemmer B: Deterioration of previous acute lung injury during neutropenia recovery. Crit Care Med 2002, 30:781-786.

11. Azoulay E, Thiéry G, Chevret S, Moreau D, Darmon M, Bergeron A, Yang K, Meignin V, Ciroldi M, Le Gall JR, Tazi A, Schlemmer B: The prognosis of acute respiratory failure in critically ill cancer patients. Medicine (Baltimore) 2004, 83:360-370.

12. Karlin L, Darmon M, Thiéry G, Ciroldi M, de Miranda S, Lefebvre A, Schlemmer B, Azoulay E: Respiratory status deterioration during G-CSF-induced neutropenia recovery. Bone Marrow Transplant 2005, 36:245-250.

13. Azoulay E, Attalah H, Yang K, Herigault S, Jouault H, Brun-Buisson C, Brochard L, Harf A, Schlemmer B, Delclaux C: Exacerbation with granulocyte colonystimulating factor of prior acute lung injury during neutropenia recovery in rats. Crit Care Med 2003, 31:157-165.

14. Todeschini G, Murari C, Bonesi R, Pizzolo G, Verlato G, Tecchio C, Meneghini V Franchini M, Giuffrida C, Perona G, Bellavite P: Invasive aspergillosis in neutropenic patients: rapid neutrophil recovery is a risk factor for severe pulmonary complications. Eur J Clin Invest 1999, 29:453-457.

15. Azoulay E, Attalah H, Harf A, Schlemmer B, Delclaux C: Granulocyte colonystimulating factor or neutrophil-induced pulmonary toxicity: myth or reality? Systematic review of clinical case reports and experimental data. Chest 2001, 120:1695-1701.

16. Ottmann OG, Bug G, Krauter J: Current status of growth factors in the treatment of acute myeloid and lymphoblastic leukemia. Semin Hematol 2007, 44:183-192.

17. Azoulay E, Mokart D, Rabbat A, Pene F, Kouatchet A, Bruneel F, Vincent F, Hamidfar R, Moreau D, Mohammedi I, Epinette G, Beduneau G, Castelain V, de Lassence A, Gruson D, Lemiale V, Renard B, Chevret S, Schlemmer B: Diagnostic bronchoscopy in hematology and oncology patients with acute respiratory failure: prospective multicenter data. Crit Care Med 2008, 36:100-107.

18. Soares M, Caruso P, Silva E, Teles JM, Lobo SM, Friedman G, Dal Pizzol F, Mello PV, Bozza FA, Silva UV, Torelly AP, Knibel MF, Rezende E, Netto JJ, Piras C, Castro A, Ferreira BS, Réa-Neto A, Olmedo PB, Salluh Jl; Brazilian Research in Intensive 
Care Network (BRICNet): Characteristics and outcomes of patients with cancer requiring admission to intensive care units: a prospective multicenter study. Crit Care Med 2010, 38:9-15.

19. Lehrnbecher T, Koehl U, Wittekindt B, Bochennek K, Tramsen L, Klingebiel T, Chanock SJ: Changes in host defence induced by malignancies and antineoplastic treatment: implication for immunotherapeutic strategies. Lancet Oncol 2008, 9:269-278. doi:10.1186/cc8198

Cite this article as: Azoulay E, Darmon M: Acute respiratory distress syndrome during neutropenia recovery. Critical Care 2010, 14:114. 